\title{
TEMA SENTRAL DALAM PEMIKIRAN JEAN PAUL SARTRE
}

\author{
Ahmad Syukri \\ alfauzi_fairus@uinsultha.ac.id \\ Universitas Islam Negeri Sultan Thaha Jambi
}

\begin{abstract}
Abstrak: Sartre's philosophical thinking was a reaction to the situation in the first and second world wars, which he considered a humanist. The order of life oriented to materialism and idealism. humans are only considered objects, as 'parts' in large machines called societies and countries. .the relationship between humans and their environment becomes very formal, their thinking is based on profit and loss, everything that does not bring use / productive is considered to be worthless. Sartre's thinking offers a way of liberation by re-enlivening the conversation about human values, by opening up new possibilities that are better for the future life of humans. sartre again directed his analysis to the main problem about who is human who has freedom, independence and as an autonomous personal being.
\end{abstract}

Keywords: Philosophy, reaction, freedom, independence

\section{A. PENDAHULUAN}

Renaissance Eropa menjadikan dunia berputar pada orbit baru, yang merupakan pondasi bagi bangunan peradaban modern. Orde baru yang progresif-inovatif ini menggeser segala bentuk pemikiran dan kekuasaan tradisional. Columbus menumbangkan gagasan-gagasan kuno, memutar-balikkan kondisi-kondisi produksi, kekayaan dan kekuasaan, Machiavelli membebaskan pemerintah dari pengekangan hukum, Copernikus menanamkan suatu kekuatan revolusioner yang meletakkan dasar-dasar bagi kemajuan ilmu pengetahuan. Runtuhnya orde tradisional membawa pergeseran wacana dalam sejarah peradaban manusia. Kalau masyarakat tradisional selalu melihat ke belakang, dimana masa lampau adalah masa sekarang, yang diawali adanya pra anggapan tentang adanya 'dunia' yang harus diikuti, maka rasionalitas modern menggusur nilai-nilai tersebut. Di masa modern orang tidak lagi 'menerima' segala bentuk romantisme masa lalu sebagai suatu yang harus dilakukan dalam kehidupan kekinian, namun dia melihat realitas kehidupan kekinian guna mewujudkan masa depan yang sesuai dengan harapan kemanusiaannya.

Apabila renaissance merupakan akar bagi bangunan pemikiran Eropa dan peradaban manusia, maka aufklaerung menyediakan kondisi-kondisi yang merupakan katalis bagi industrialisasi, kapitalisme dan sosialisme, serta perubahan sosial menuju demokrasi. Derasnya perkembangan sains dan teknologi sebagai konsekuensi 
perkembangan ini sudah tidak terbendung. Hal ini menjadi menarik ketika fenomena dalam kehidupan kemanusiaan menunjukkan terjadinya manufactured uncertainty, masa yang diliputi oleh ketidakpastian yang mewarnai kehidupan masyarakat manusia memasuki abad ke21 ini yang membawa pada high consequence risk. Situasi ini menarik karena fenomena tersebut muncul bukan berasal dari alam, namun sebagai akibat dari ulah manusia dengan sains dan teknologi yang diciptakannya.

Kondisi ekonomi dan politis masyarakat modern telah meningkatkan keterkucilan dan ketidakberdayaan individu. Ketidakberdayaan pada gilirannya memunculkan hasrat untuk melarikan diri, atau bila tidak, akan membawa seseorang pada kompromi yang dipaksakan, dimana individu yang terkucil menjadi makhluk hidup yang bergerak dan berpikir serupa mesin, serba otomatis. Individu kehilangan hakikat dirinya sendiri, namun secara sadar ia menganggap dirinya bebas, dan tunduk pada dirinya sendiri saja. Manusia terbenam dalam khayal tentang kejayaan individualitas.

Manusia dalam demokrasi modern, mungkin dapat berbangga bahwa dirinya memiliki kewenangan-kewenangan untuk merealisasikan diri sebagai individu yang utuh, dan bukan sebagai subjek kewenangan dari luar. Manusia bebas mengungkapkan gagasan dan perasaannya, kemerdekaan merupakan garansi yang nyaris otomatis bagi individualitas. Namun yang perlu dicermati adalah bahwa hak untuk mengutarakan pemikiran hanyalah akan dapat berarti bila orang mampu memiliki pikiran sendiri. Kebebasan dari kewenangan dari luar hanya bisa bermakna jika kondisi kejiwaan individu yang terdalam memiliki wajah tertentu hingga dia dapat menetapkan individualitasnya sendiri.

Konteks keindonesiaan, negara Republik dengan bangunan Demokrasi Pancasila-nya ternyata telah membuat sebuah tatanan--yang didirikan oleh orde baru--berupa birokratisasi kebebasan yang dikombinasi dengan personalisasi kekuasaan yang merepresi segala bentuk perjuangan kebebasan Individu sebagai hak otonomi subjek yang 'dipenjara' dalam ideologi 'ketimuran'. Hal tersebut menjadi semakin naif, ketika tumbangnya 'orde baru' sebagai peletak dasar 'jerat kebebasan' membawa kepada anarki perilaku individu untuk melampiaskan kebebasan dengan hak-hak yang dimiliki.

Fenomena di atas membawa dampak terhadap munculnya permasalahan mendasar tentang apakah sebenarnya kebebasan itu, dan kenapa harus dihargai? apakah keinginan yang bebas itu merupakan sesuatu yang telah tertanam dalam watak manusia, ataukah merupakan hasil dari suatu situasi khusus? apakah dia diinginkan sebagai tujuan akhir atau sebagai alat untuk mencapai hal-hal lain? dan apakah bila seseorang memiliki kebebasan harus memiliki pula tanggung jawab atas kebebasannya? Pembahasan berikut ini dengan telaah deskriptif-interpretatif akan menguraikan pandangan seorang tokoh eksistensialis Jean Paul Sartre, tentang makna kebebasan dalam kehidupan manusia.

\section{B. SETTING KEHIDUPAN DAN SARTRE}

Jean Paul Sartre adalah tokoh yang sangat berperan pada penyebaran filsafat eksistensialisme. Hal ini banyak disebabkan oleh pemikiran filsafatnya yang senantiasa dihubungkan dengan realitas nyata kehidupan, yang ditopang 
dengan kepandaiannya sebagai sastrawan yang juga mendukung penyampaian pelbagai ide filosofis yang disuguhkannya dalam bentuk roman dan pentas dengan bahasa yang dapat mempengaruhi pembaca dan penggemarnya.

Terlahir di Paris tanggal 21 Juni 1905, ayahnya perwira angkatan laut dan Ibunya Anne Marie Scheweitzer anak satu-satunya dari Charles Scheweitzer seorang guru bahasa dan sastra Jerman. Dalam kehidupannya, Sartre banyak diasuh oleh Sang kakek, sehingga banyak pemikiran sastra yang diwarisinya. Walaupun Sartre pernah dibaptis dan dibesarkan di lingkungan Katolik, namun dia mengakui dalam bukunya Les Most (1964) bahwa sejak usia 12 tahun dia tidak lagi percaya adanya Allah, dan seakan-akan kesusasteraan menjadi agama baru baginya. Pada usia 8 tahun Sartre sudah memutuskan untuk ingin menjadi pengarang besar, yang bagi dia saat itu adalah pengarang yang mis understood (yang salah dipahami sidang pembaca).

Setelah menyelesaikan studinya (1929) di Ecole Normale Supericure, dia berkenalan dengan Simone de Beauvoir, mahasiswa filsafat universitas Sorborne, pertemuan yang merupakan titik tolak persahabatan mereka, dan dari otobiografi karya Simone inilah banyak diketahui perkembangan pemikiran Sartre. Setelah diangkat sebagai guru muda di universitas yang sama, Sartre termasuk intelektual yang berhaluan kiri dengan obyek kritiknya terutama kaum borjuis dengan norma-norma dan tradisinya. Di bidang filsafat Sartre dan kawan-kawannya menyerang idealisme dan setiap pemujaan terhadap 'hidup batin'. Mereka mengkritik profesor-profesor di universitas yang mengandaikan perubahan kemasyarakatan dengan ide-ide atau koreksi terhadap ide. Kritik ide ini juga banyak dipengaruhi oleh perang dunia I dan revolusi di Rusia.

Tahun 1933 Sartre mulai berkenalan dengan fenomenologi Husserl, yang kemudian ia pelajari lebih dalam pada 'Lembaga Prancis' di Berlin. Sebagai hasil studinya ini Sartre menulis artikel panjang berjudul La Transendence de L'ege (transendensi ego). Sejak semula dia berpandangan bahwa filsafat ini merupakan suatu sarana untuk mengungkapkan realitas dan pengalaman yang kongkrit.

Ketika perang dunia II pecah, Sartre di panggil untuk memenuhi tugas wajib militer. Karena dia bertugas di bagian meteorologi, maka banyak waktu luang yang kemudian dia gunakan untuk membaca dan menulis. Ia juga sempat mendekam di tahanan sebagai tahanan perang pada Juni 1940-April 1941. Pada tahun 1943 terbitlah karya filsafatnya yang paling terkenal; $L$ 'etre et le neant (ada dan ketiadaan; percobaan suatu ontologi fenomenologis). Dengan buku ini Sartre menjadi filsuf ternama dan segera dianggap sebagai salah satu pemimpin gerakan filosofis yang disebut dengan eksistensialisme. Salah satu tanda kepopulerannya adalah suksesnya buku kecil yang berjudul L'existentialisme est un Humanisme (1946). Buku ini merupakan rangkuman pemikirannya pada saat itu dan membela eksistensialisme dari keberatan yang dikemukakan kaum komunis.

\section{TITIK-TOLAK PEMIKIRAN SARTRE}

Premis filsafat Sartre banyak diuraikan dengan pelbagai istilah 'revolusioner' di pertengahan abad 20. Misalnya pernyataan yang mengatakan bahwa eksistensi itu mendahului esensi 
(hal ini dikenal dalam eksistensialisme dengan semboyan existence precedes essense), tidak ada hakikat manusia, karena tidak ada Tuhan yang memiliki konsepsi tentang hal itu. Esensi sebagai bangunan intelektual akan hilang bersama dengan akal yang memahaminya.

Bagi filsuf eksistensialis, termasuk Sartre, eksistensi adalah premis awal dari penelitian. Eksistensi ini tidak ditentukan oleh sesuatu gagasan yang universal, dan tidak punya tujuan yang dibayangkan terlebih dahulu seperti apa yang mungkin terkandung dalam suatu pandangan tentang hakikat manusia. Dia hanya sepenuhnya bereksistensi jika dia merupakan apa yang dia maksudkan. (hal ini mirip dengan pandangan Heidegger) ${ }^{1}$.

Titik tolak filsafat menurut Sartre tidak bisa lain dari pada cogito ; kesadaran yang saya miliki tentang diri saya sendiri. Dalam hal ini, Sartre mengakui kebenaran Descartes. Tetapi filsuf abad 17 ini menurut Sartre langsung menafsirkan cogito sebagai suatu cogito yang tertutup, sehingga cogito yang terpisah dari dunia dan terkurung dalam dirinya. Untuk itu kemudian Sartre memasukkan pandangan Husserl yang menyatakan bahwa intensionalisme merupakan ciri khas kesadaran. Menurut kodratnya kesadaran terarah kepada yang lain dari dirinya. Menurut kodratnya kesadaran adalah transendensi (bertentangan dengan imanensi yang menandai cogito Descartes).

Walaupun menggunakan pendekatan Husserl namun Sartre beranggapan bahwa fenomenolog ini tidak memberikan penjelasan yang memuaskan

\footnotetext{
${ }^{1}$ Roger Scruton, (1986), Sejarah Filsafat Barat Modern (dari Descartes Sampai Wittgenstein) (terj. Zainal Abidin), Pantja Simpati, Jakarta, h. 321.
}

tentang adanya fenomena-fenomena. Permasalahan yang dirasa ganjil dalam pandangan Husserl menurut Sartre adalah apakah adanya fenomena-fenomena juga merupakan fenomena atau tidak? Bagi Husserl adanya suatu objek tidak berbeda secara principle dengan tampaknya objek itu. Husserl berhenti pada esensi atau eidos, tetapi dengan itu dia tidak pernah mencapai Ada-nya suatu objek. Sartre berkeyakinan bahwa Ada merupakan syarat bagi tampaknya sesuatu. Ada itu selalu bersifat trans-fenomenal. Kalau orang tidak mau menerima ini, maka mau tidak mau ia akan jatuh pada idealisme, karena telah menggantungkan Ada pada subjek. Perumusan yang masyhur bagi pandangan ini berasal dari Berkeley 'Esse est Percipi' (adanya sesuatu itu karena dipersepsi). Jadi dalam menentukan hubungan antara kesadaran dengan Ada, tidak mungkin bahwa Ada itu fenomena belaka, karena Ada bersifat transendental; tidak dapat dijadikan fenomena saja, tidak pernah dapat dilampaui polaritas antara kesadaran dengan $\mathrm{Ada}^{2}$.

Atas dasar itu, kemudian Sartre mempertanyakan tentang apakah yang dapat dikatakan tentang Ada-nya kesadaran?, Sudah diketahui bahwa kesadaran itu bersifat intensional; menurut kodratnya terarah kepada dunia. Hal itu dirumuskan oleh Sartre dengan 'kesadaran (akan) dirinya' berada sebagai 'kesadaran akan sesuatu'. Kesadaran adalah kesadaran diri (self conciousness), tetapi kesadaran (akan) dirinya tidak sama dengan pengalaman tentang dirinya; mengambil dirinya sebagai objek pengenalan. Cogito bukanlah pengenalan diri, melainkan kehadiran kepada dirinya secara non tematis. Karena alasan ini kata

${ }^{2}$ K. Bertens, (1996), Filsafat Barat Abad XX PRANCIS, Gramedia, Jakarta, h. 91. 
'akan' oleh Sartre ditulis dalam tanda kurung. Jadi harus dibedakan kesadaran tematis dan kesadaran non tematis; kesadaran akan sesuatu dan kesadaran (akan) dirinya. Itu berarti bahwa cogito yang merupakan titik tolak dari filsafat Sartre adalah cogito pra refleksif. Kesadaran (akan) dirinya 'membonceng' pada kesadaran akan dunia. Itu berarti juga bahwa cogito tidak menunjuk pada suatu relasi pengenalan, melainkan pada suatu relasi Ada. Kesadaran adalah kehadiran (pada) dirinya. Kehadiran (pada) dirinya merupakan syarat yang perlu dan cukup untuk kesadaran. Dari sini terlihat penolakan Sartre terhadap subjek transendental atau $\mathrm{Aku}$ absolut seperti diterima oleh idealisme.

\section{PEMIKIRAN SARTRE}

Tema sentral yang terdapat dalam seluruh karya filsafat Sartre adalah manusia atau lebih spesifik menekankan human existence. Salah satu ungkapan Sartre yang menunjukkan hal ini adalah 'hanya manusia yang sungguh-sungguh bereksistensi' ${ }^{3}$. Warna dominan dalam filsafatnya adalah humanistis. Semua pemikiran filsafatnya boleh dikatakan sebagai usaha untuk melukiskan cara beradanya (the mode of being) manusia. Dalam pandangannya diungkapkan bahwa manusia tidak lain dari pada bagaimana dia menjadikan dirinya sendiri, mengungkapkan cita-cita manusia yang mengalir secara mendalam sebagai sebuah kepastian yang sebenarnya dari apa seharusnya menjadi seorang manusia, cita-cita untuk menentukan keberadaan individu seseorang dalam suatu kebutuhan

${ }^{3}$ F.A., Olafson, (1976), Jean Paul Sartre dalam Paul Edward, Encyclopedia of Philosophy, Vol VII, Mic Millan, Newyork, h. 288. rasional atau sejenisnya. Dengan kata lain, bagi manusia, eksistensi adalah keterbukaan, berbeda dengan 'ada' lain, dimana 'ada' itu sekaligus esensi. Oleh karena itu bagi manusia eksistensi mendahului esensi.

Sartre memandang manusia sebagai subjek, manusia adalah pencipta dirinya sendiri yang terus menerus. Manusia terus menerus mencipta dirinya sendiri dengan kemauan, kemerdekaan dan perbuatannya. Dengan kebebasannya manusia dapat mencipta, ia ditandai oleh keterbukaan pada masa depan dan merencanakan segala sesuatu bagi dirinya. Ia tidak dapat menyalahkan orang lain atau menggantungkan diri kepada realitas yang tidak ada (Tuhan), tetapi manusialah yang senantiasa menciptakan dirinya sendiri. Manusia adalah pengada yang tidak pernah identik dengan dirinya sendiri. Setiap kali ia menciptakan dirinya, sekaligus meniadakan dirinya yang sudah ada.

Driyarkara dalam bukunya Percikan Filsafat menegaskan bahwa dalam pandangan Sartre manusia selalu mengingkari (neantisation). Manusia tidak pernah menjadi dirinya sendiri, oleh karena itu usaha untuk mencapai dirinya yang penuh tidak pernah berhasil. Menurut Sartre manusia terkutuk untuk gagal, maka eksistensi itu memuakkan (Nausea).

\section{E. EKSISTENSI KEBEBASAN MANUSIA}

Konsep Sartre tentang eksistensi manusia terkait dengan pandanganya tentang ada dan berada (being and doing). Untuk menunjukkan Ada dan Berada Sartre menciptakan Istilah L'etre-en-soi (being-in-itself/berada-dalam-diri) dan L'etre-pour-soi (being-for-itself/berada- 
untuk-diri). Yang dimaksud dengan berada-dalam-diri adalah semacam berada an sich, berada dalam dirinya, berada itu sendiri. Filsafat berpangkal dari realitas yang ada, sebab realitas yang ada itulah yang kita hadapi, kita tangkap, kita mengerti. Ada banyak yang berada; pohon, batu, binatang, manusia dan sebagainya. Semuanya itu berbeda-beda, banyak ragamnya, akan tetapi ada sebutan umum bagi semua itu, yaitu semua itu 'ada' atau 'berada'. Berada mewujudkan ciri segala benda jasmaniah, segala materi. Semua benda ada-dalam-diri atau adadalam-dirinya-sendiri. Tidak ada alasan atau dasar mengapa benda-benda itu berada begitu (apa sebab meja itu meja, dan bukan kursi, serta bukan tempat tidur, tiada alsannya). Segala yang beradadalam-diri ini tidak aktif, tetapi juga tidak pasif, tidak mengiyakan tetapi juga tidak menyangkal. Semuanya dikatakan padat, beku, tertutup. Yang satu lepas dari yang lain, tanpa saling berhubungan. 'Etre-ensoi mentaati prinsip identitas (it is what it $i s$ ). Benda-benda tidak memiliki hubungan dengan keberadaannya. Meja itu ada, meja itu warnanya demikian, titik. Kita dapat mengatakan bahwa meja bertanggungjawab atas fakta bahwa ia adalah meja, bahwa warnanya demikian dan sebagainya.

Etre-en-soi menyatakan it is what it is. Etre-in-soi harus identik dengan dirinya. Etre-en-soi tidak aktif, tidak pasif, tidak afirmatif, tidak negatif ; kategori kategori semacam itu hanya memiliki arti dalam kaitan dengan manusia. Etre-en-soi tidak memiliki masa silam, masa depan; tidak memiliki kemungkinan maupun tujuan. Etre-en-soi itu sama sekali kontingen. Artinya; ada begitu saja, tanpa fundamen, tanpa diciptakan, tanpa dapat diturunkan dari sesuatu yang lain.
Sartre di sini menggunakan istilah kontingen dan kontingensi dalam arti baru. Dalam filsafat klasik, kontingen adalah lawan dari niscaya atau mutlak perlu. Bagi Thomas Aquinas dan Descartes umpamanya; 'dunia adalah kontingen' berarti bahwa dunia bisa ada dan bisa pula tidak ada. Karena itu bagi mereka kontingensi adalah apa yang harus dijelaskan. Dan kontingensi itu sudah berhasil dijelaskan ketika orang mampu menunjukkan sesuatu yang mutlak perlu (ens necessarium). Dengan demikian menurut mereka kontingensi justru merupakan titik tolak suatu bukti untuk adanya Allah. "Dunia adalah kontingen" bagi mereka berarti; kita hanya mengerti adanya dunia, jika kita menerima suatu penyabab yang mutlak perlu, yaitu Allah. Tetapi bagi Sartre kontingensi ialah apa yang tidak perlu dijelaskan. Kausalitas justru mengandaikan Ada. Bagi Sartre kausalitas adalah relasi yang ditambahkan manusia pada Ada. Tetapi Ada itu sendiri ada begitu saja. Kiranya sudah jelas bahwa disini tidak saja tampak suatu arti baru bagi istilah lama, tetapi juga suatu pandangan menyeluruh yang sama sekali lain. Pandangan itu tampil pada halamanhalaman termasyhur dari novel La nausee (rasa muak) yang melukiskan pengalaman Roquentin dalam taman kota (agaknya semacam ilham yang penah dialami Sartre sendiri). Di situ sudah digunakan istilah kontingensi.

"The essential thing is contingency. I mean that, by definition, existence is not necessity. To exist is simply to be there ; what exist appears, lets itself be encountered, but you can never deduce it,.... No necessary being can explain existence; contingency is not an illussion, an appearance which can be dissipated; it is absolute, and 
konsequently perfect gratuitousness. Everything is gratuitous, that park, this town, and my self. When you realize that, it turns your stomach over and everything starts floating about.... that is the Nausea"4.

Pada bagian lain, dalam L'etrepour-soi atau berada-untuk-diri ialah berada yang sadar akan dirinya. Sartre menganggap hal ini sebagai cara berada manusia. Etre-pour-soi tidak mentaati prinsip identitas seperti etre-en-soi. Manusia mempunyai hubungan dengan keberadaanya, ia bertanggung jawab atas fakta bahwa ia seorang pegawai atau pedagang atau pencuri dan sebagainya. Benda-benda tidak sadar bahwa dirinya ada tetapi manusia sadar bahwa dirinya berada. Di dalam kesadaran ini, yaitu di dalam kesadaran yang disebut reflektif. Ada yang menyadari dan ada yang disadari, ada subjek dan objek. Hal yang demikian tidak terdapatlah pada benda. Oleh karena itu seperti yang dijelaskan di atas, benda adalah padat, penuh dengan diri sendiri, tertutup bagi yang lain, tanpa hubungan dengan yang lain. Dapat dikatakan bahwa benda adalah buta, gelap. Benda adalah benda, hanya ada saya. Benda adalah dia sendiri. Akan tetapi tidaklah demikian dengan manusia, pada manusia ada kesadaran yaitu kesadaran yang reflektif dan pra reflektif. Perbedaan ini dapat dijelaskan dengan contoh; Aku sedang menutup buku kasku pada bulan ini, oleh karena itu aku sibuk menghitung segala pengeluaranku. Perhatianku kucurahkan pada angkaangka di dalam buku kasku itu. Angkaangka itulah yang menjadi tema

\footnotetext{
${ }^{4}$ Jean Paul Sartre, (1973), NAUSEA

(translated by R. Baldick), penguin books, Harmondworth, h. 188.
}

perhatianku. Bahwa aku sedang menghitung memang kusadari (sebab aku tidak pingsan saat menghitung) akan tetapi perbuatan menghitung itu pada waktu itu tidak menjadi pusat perhatianku. Perbuatan menghitung itu hanya ada di periferi atau disekitar perhatianku. Bentuk kesadaran yang tidak ada di pusat inilah yang disebut dengan kesadaran pra reflektif (kesadaran yang belum dipikirkan kembali). Pada waktu aku sedang sibuk menghitung datanglah temankku yang bertanya: 'Kamu sedang apa?' aku berhenti menghitung dan menjawab; 'aku sedang menghitung'. Pada waktu inilah aku menyadari bahwa aku sedang menghitung. Pada waktu inilah perhatianku kuarahkan kepada perbuatan menghitung itu sendiri, bukan kepada angka-angka yang dihitung. Bentuk kesadaran ini disebut dengan kesadaran reflektif (kesadaran yang dipikirkan kembali atau kesadaran yang telah kembali kepada diri sendiri). Selesai menghitung aku pergi dengan teman ke toko. Kesadaran pra refleksif pada waktu itu tidaklah hilang, yang hilang adalah kesadaran menghitung, kesadaran bahwa aku menghitung, sebab timbullah kesadaran yang baru bahwa aku sedang pergi ke toko, dan lain sebagainya ${ }^{5}$.

Bagi Sartre kesadaran tidak boleh dipisahkan dari dunia. Suatu hal lain yang ditekankan Sartre ialah bahwa kesadaran sekali-kali tidak boleh disamakan dengan benda. Bagi Sartre sebagaimana dijelaskan di atas bahwa kesadaran (akan) dirinya berada sebagai kesadaran akan sesuatu. Dengan kata lain kesadaran adalah intensional. Rumusan ini dapat dibalik dengan: kesadaran akan sesuatu

${ }^{5}$ Harun Hadiwijono, (1998), Sari Sejarah Filsafat II, Kanisius, Yogyakarta, h. 159. 
berada sebagai kesadaran (akan) dirinya. Kehadiran (pada) dirinya sendiri adalah konstitutif bagi kesadaran. Suatu maksud, rasa senang, sedih atau yang lainnya hanya bisa berada sebagai sadar (akan) dirinya; persis suatu benda tidak mungkin berada kecuali dengan memiliki tiga dimensi. Suatu kesadaran yang tidak sadar atau suatu aktifitas psikis yang tidak sadar (bandingkan dengan psikoanalisa Freud) bagi Sartre sama sekali mustahil ${ }^{6}$. Kehadiran (pada) dirinya sendiri yang mengkonstitusikan kesadaran itu sebagai non-tematis. Bagaimana dapat kita mengerti bahwa manusia tidak langsung sadar akan dirinya?, apakah yang memungkinkan hal itu?

Pertanyaan-pertanyaan tersebut di atas, dijawab Sartre; Kalau saya sadar akan sesuatu, itu berarti juga bahwa saya bukan 'sesuatu' itu, bahwa saya tidak sama dengan 'sesuatu' itu. Saya melihat lukisan di dinding, itu berarti saya sadar bahwa saya bukanlah lukisan. Untuk melihat sesuatu diperlukan sesuatu syarat yang mutlak; yaitu adanya jarak. Bila sesuatu dekat sekali dengan mata, apalagi bila sesuatu identik dengan mata (misalnya retina atau selaput jala), saya tidak akan melihat apa-apa. Dari contoh ini dapat ditarik kesimpulan bahwa negativitas merupakan ciri khas entrepour-soi. Manusia sanggup untuk mengadakan relasi dengan yang tidak ada. Tentang etre-pour-soi harus dikatakan: it is what it is. Kesadaran berarti distansi, jarak, non-identitas ${ }^{7}$.

\section{F. MANUSIA DAN KEBEBASAN}

${ }^{6}$ M.A.W. Brouwer, (1989), Psikologi Fenomenologis, Gramedia Jakarta, h. 142.

${ }^{7}$ Jones, W.T, (1975), The Twentieth Century to Wittgenstein and Sartre (a History of Western Philosophy), California Institute of Technology, New York, h. 245.
Dalam sejarah perkembangan filsafat, Sartre adalah tokoh yang ekstrem dan radikal dalam mengungkapkan konsep-konsep tentang kebebasan. Pandangannya yang revolusioner, progresif dan berhaluan kiri selalu tampak dalam pemikirannya. Bahkan dia sendiri menyatakan bahwa dirinya adalah seorang yang 'anarkis' sejak masa mudanya ${ }^{8}$. Rumusan pemikiran Sartre tentang kebebasan, banyak berpijak pada pokokpokok pikirannya tentang eksistensi manusia dan kesadaran. Bagi Sartre manusia adalah kebebasan. Manusia adalah satu-satunya makhluk dimana eksistensi mendahului esensi ${ }^{9}$, ...that man's existence precedes his essence.... man first of all exist, encounter himself, surges up in the world and defines after warlds ${ }^{10}$.

Memang rumusan ini ekstrim, tidak cukup kalau dikatakan bahwa manusia memiliki kehendak yang bebas, tidak cukup kalau dikatakan bahwa kebebasan merupakan salah satu ciri atau sifat manusia, tidak cukup juga kalau dikatakan bahwa kebebasan manusia merupakan ciri khas atau sifat hakiki manusia. Sebab menurut Sartre, manusia adalah satu-satunya makhluk yang tidak memiliki kodrat atau esensi. Seandainya terdapat kodrat atau esensi manusia, maka manusia itu tidak bebas, manusia berarti begini atau begitu, sesuai dengan yang telah ditentukan. Dan hal ini menurut Sartre tidaklah mungkin. Yang menjadi permasalahan kemudian adalah apakah

\footnotetext{
${ }^{8}$ K. Bertens, Op.Cit., h. 165.

${ }^{9}$ Jean Paul Sartre, (1960), Existentialism is Humanism, Trans. Philip mainet, Meutheun co. ltd.. London, h. 26.

${ }^{10}$ I.M. Wallace, (1968), A History of Philosophy, Published by Van Nostrud, Reinhold Company, Newyork, h. 474-475; K. Bertens, Op.Cit., h. 314.
} 
manusia itu, apakah kodratnya, apakah esensinya?. Hal ini dijawab oleh Sartre; man is nothing else but that which he makes of him self, that is the first principle of existentialism (manusia tidak lain daripada bagaimana dia menjadikan dirinya sendiri, demikian azas pokok dari eksistensialisme) $)^{11}$. Sartre juga menganggap bahwa manusia adalah rancangan masa depan, ia selalu terbuka, ia adalah perkembangan diri yang terus menerus, masa kininya sekaligus merupakan masa depannya, sebab apa yang diciptakan kini adalah proyeksi ke masa depan ${ }^{12}$.

Pendapat Sartre tentang kebebasan itu berhubungan dengan pembedaanpembedaan cara berada: Etre-en-soi (being in itself) dan Etre-pour-soi (being for it self). Manusia dalam membangun dirinya selalu berbuat dan meniadakan dirinya dengan kesadaran yang sepenuhpenuhnya. Dalam perbuatan itu manusia dihadapkan pada pilihan-pilihan, dia harus memilih dan menentukan sendiri apa yang menjadi idealnya. Manusia dalam menentukan pilihan bebas tidak ada yang mempengaruhinya. Manusia dalam momentum semacam ini berusaha membangun dan membentuk dunianya. Kalau tidak demikian, maka dialah yang akan dibentuk dan dibangun dunianya. Konsekuensinya manusia yang memiliki kebebasan hanya ada satu pilihan baginya, yaitu dia senantiasa dituntut untuk membangun dunianya agar kebebasannya tetap terjamin dan dimiliki secara pasti.

Kebebasan manusia dalam pandangan Sartre itu bersifat absolut.

\footnotetext{
${ }^{11}$ Jean Paul Sartre, (1960), Op.Cit., h. 28.

${ }^{12}$ Fuad Hasan, (1989), Berkenalan dengan Eksistensialisme, Pustaka Jaya, Jakarta, h. 146.
}

Kebebasan manusai adalah total ${ }^{13}$. Tidak ada batas-batas bagi kebebasan selain batas-batas yang ditentukan bagi kebebasan itu sendiri. Tanpa kebebasan, eksistensi menjadi penjelmaan yang absurd. Sebab jika kebebasan ditiadakan, maka manusia hanyalah menjadi esensi belaka. Bagi Sartre manusia dan kebebasannya adalah satu kesatuan yang tidak dapat dipisahkan dan ditiadakan. Konsekuensi dari pilihan-pilihan untuk tindakan, manusia bertanggungjawab terhadap apa yang dipilihnya. Ia bertanggungjawab terhadap perbuatannya sendiri dan terhadap sesuatu diluar dirinya sendiri. Artinya bahwa dia tidak bisa memikul tanggungjawabnya kepada orang lain atau sesuatu di luar dirinya untuk memenuhi harapan-harapannya sebagai pemberi kepastian-kepastian. Maka bagi Sartre kebebasan itu dirasakan pula sebagai kecemasan (Bertens, 1996: 320321).

Pandangan radikal Sartre tentang kebebasan ini terkait dengan pandangan atheisnya:

If God did not exist, everything would be permitted, and that, for existentialism, is the starting point. everything is indeed permitted if God does not exist, and man is consequence for lorn, for he can not find anything to depend upon either within or outside him self.... for if indeed existence precedes essence. one will never be able to explain one's action by reference to given and specific human nature (Sartre, 1960: 23-24).

${ }^{13}$ J. Omoregbe, (1976), The Positive and Negative Aspect of Jean Paul Satre's Conception of Human Freedom, Oyes Leuven, Roma, h. 20. 
Ungkapan ini mengandung arti bahwa seandainya terdapat Allah, maka saya menjadi objek dengan kodrat tertentu. Jika demikian, maka satu kali untuk selamanya sudah ditentukan siapa saya. Oleh karena itu salah satu alasan yang mendorong Sartre untuk menolak adanya Allah adalah kebebasan manusiawi. Maka atheisme Sartre dapat dirumuskan sebagai berikut; karena manusia itu bebas, maka Allah itu tidak ada, dengan kata lain, jika Tuhan tidak ada, maka manusia bukanlah suatu makhluk yang sudah dicetak sebelumnya, melainkan suatu proyek ke masa depan yang tidak mungkin untuk didefinisikan. Jadi tidak terdapat nilai-nilai abadi di dalam suatu dunia di atas manusia. Pandangn Sartre ini menimbulkan sebuah pertanyaan tentang bagaimana konsep kebebasan itu berlaku dalam kaitannya dengan tingkah laku dan kedudukan manusia sebagai makhluk etis sehingga kehidupan yang manusiawi dapat terwujud?

Sartre memiliki pandangan bahwa human reality is free, basically and completelly free ${ }^{14}$, kebebasan tidak bertumpu kepada sesuatu yang lain, selain kebebasan itu sendiri ${ }^{15}$. Manusia adalah kebebasan total, ia dihukum untuk bertindak bebas. Manusia hidup pada tahap ketiadaan, pour-soi, kesadaran, dalam subjektivitas murni. Melarikan diri dari kebebasan pada dasarnya adalah suatu cara bagaimana manusia dapat merealisasikan kebebasannya.

Dalam kaitannya dengan tingkah laku dan kedudukan manusia sebagai

\footnotetext{
${ }^{14}$ Jean Paul Sartre, (1958), Op.Cit., h. 197.

${ }^{15}$ Jean Paul Sartre, (1976), Huis Clos (Pintu Tertutup), Versi Indonesia oleh Asrul Sani, Pustaka Jaya, Jakarta, h. 439.
}

makhluk etis, Sartre menolak dengan tegas segala bentuk objektivitas, sebab bentuk yang telah ditentukan itu akan membelenggu manusia sebagai makhluk yang bebas. Ia berpendapat bahwa moral yang dijadikan dasar segala refleksi sikap dan tindakan manusia adalah dengan cara meninggalkan segala bentuk objektivitas seraya mengakui diri sendiri sebagai pusat dan asal usul segala nilai. Menurut Sartre, keberadaan manusiawi hanya mungkin atas dasar suatu kebebasan total yang mencipta. Apabila manusia adalah kebebasan yang mencipta secara total, maka ia menyempurnakan dirinya sendiri, ia adalah suatu rancangan untuk masa mendatang.

Menurut Sartre, tindakan manusia itu bersifat intensional, artinya, terarah kepada sesuatu yang berlainan dengan tindakan itu sendiri, punya tujuan yang disengaja dan tujuan itu ada di masa depan. Pertanyaan yang muncul adalah mengapa manusia bertindak? Sartre menjawab, karena manusia 'menyadari' adanya kekurangan dalam eksistensinya. Misalnya seorang buruh yang sudah hidup layak, tidak akan protes atau mogok. Namun apabila dia melihat dan menghayait adanya kemungkinan hidup yang lebih layak, ia mulai mengambil sikap baru terhadap eksistensinya. Ia mulai melihat dan menghayati hidupnya saat ini sebagai situasi yang tidak tertahankan dan sekarang siap untuk mengambil tindakan yang memungkinkan untuk perbaikan hidupnya. Jelasnya, manusia hanya akan bertindak bila meniadakan dan melam Sartre dalam pandangannya tentang kebebasan ini menolak bahwa kebebasan merupakan pergumulan antara kehendak dan emosi. Hal ini karena Sartre memandang being for itself sebagai roh atau kehendak murni yang bertindak melalui tubuh dan 
keinginan-keinginannya. Emosi dan keinginan tidak muncul secara spontan, melainkan bersifat intensional sebagaiman disinggung di atas. Sebgai contoh, seorang tentara yang takut maju perang, disebabkan dia mau hidup. Keinginankeinginan itu berdasar penghendakan yang fundamental yang bersumber pada peniadaan being for it self. jadi kehendak dan keinginan merupakan cara dan manivestasi beradanya being for itself yang paling otentik sebagai ketiadaan dan kebebasan. Pertanyaan kemudian yang muncul adalah bagaimana dengan pertimbangan kita sebelum mengambil keputusan?

Penghendakan dan kebebasan itu merupakan pengejawan-tahan being for it self yang senantiasa meluncur ke masa depan, maka tujuan yang akan dicapainya sungguh-sungguh berasal dari being for itself sendiri. Pilihan manusia bebas itu bukan lagi berasal dari suatu pertimbangan, melainkan merupakan cara berada manusai yang mendahului dan memberi konteks pada per-timbangan. Pertimbangan itu hanya berhubungan dengan semua untuk mencapai tujuan, yaitu tujuan yang dipilh secara fundamental walaupun secara pra refleksif.

Apabila keputusan untuk melakukan tindakan tertentu dianalisa, akan menjumpai motivasi (proyek) yang dasariah. Namun Sartre tidak sependapat dengan Freud yang menyatakan bahwa motivasi dasariah itu bersifat tidak sadar atau sitentukan oleh suatu yang terjadi di masa lampau. Sartre berpendapat bahwa struktur motivasi dasariah itu haruslah dilihat dalam kesadaran yang sudah direfleksikan pada saat ini dan dalam pilihan bebas manusia untuk berada pada masa lampau yang bersifat pre refleksif.

Pilihan manusia untuk berada itu dapat terungkap dalam cara mansuai berpakaian, bertindak, mengatur kamar dan sebagainya. Masa lampau memang memberikan faktisitas kebebasan manusia, namun masa lampau bukanlah kebebasan manusia itu sendiri. Kebebasan fundamental itu tidak stabil, karena setiap pilihan memungkinkan manusia untuk membuat pilihan lain lagi ${ }^{16}$.

\section{G. KEBEBASAN DAN KENYATAAN}

Sartre menekankan bahwa kebebasan manusia bersifat absolut, meskipun berlangsungnya dalam konteks. Dengan kata lain, kebebasan itu bersituasi. Manusia dalam kebebasan itu pada akhirnya berhadapan dengan kenyataankenyataan (facticity). Konsekuensi dari faktisitas ini, maka kebebasan menjadi terhambat dan dirasakan sebagai suatu yang menakutkan, mengahantui. Sartre mengungkapkan; I am not 'free' either to escape the lot of my class, of my nation, of my family, or event to bulild up my own power or my fortune or to conquer my most insignificant appetites or habits.... thus freedom is the apprehension of my facticity $^{17}$.

Namun menurut Sartre kondisi yang dibawa sejak lahir dan alami bukanlah halangan kebebasan yang sebenarnya. Satu-satunya kemungkinan yang dapat membatasi kebebasan kita dalam arti tertentu adalah kebebasan

\footnotetext{
${ }^{16}$ Riyanto Sanjiwani, (1983), Kebebasan Menurut Sartre, dalam majalah Driyarkara, Tahun XI no 1, oktober, Jakarta, h. 7.

${ }^{17}$ Jean Paul Sartre, (1958), Being and Nothingness : an essay on phenomenology ontology, Transl. By H.E. Barnes, Meuthuen, London, h. 481.
} 
orang lain. Akan tetapi factisitas ini tidak begitu merisaukan, asalkan manusia menatapnya sebgai suatu kewajaran dan kenyataan sebagai pilihan-pilihan yang hadir dan sebagai konsekuensi dari kebebasannya. Walaupun faktisitas ini setiap saat melingkupi, menjerat, menakutkan manusia dan kebebasannya, namun manusia harus mengabaikan, tidak mempedulikan dan berusaha menganggap sepi dan kosong.

Faktisitas tidak mengurangi kebebasan manusia, karena manusia dapat tetap bersikap bebas dan memanipulasinya. Sartre menyebutkan ada lima macam faktisitas, yaitu, my place, my past, my environment, my fellowman, dan my death.

a. My place (tempat-ku berada)

Ia mengartikannya sebagai tempat tertib ruang dan peristiwa-peristiwa, alasan yang menghadapkan manusia pada keadaan. Tempatku berada merupakan hal yang membelenggu kebebasanku. Tempat dimana aku merasa betah dan mempolakan kebiasaan-kebiasaanku, situasi yangmenciptakan struktur bagiku, akan tetapi juga aku strukturi. Ini berarti aku tidak bisa melawan keadaan-keadaan dan situasi yang tampil ditempatku berada $^{18}$. Implikasinya 'aku' menjadi berkurang dalam pengahayatan kebebebasanku, kebebasanku terdesak.

Walaupun demikian, tempatku berada, tempat yang aku alami, bisa menjadi landasan bagi tindakantindakanku, tetapi dapat pula kutinggalkan dengan kebebasan. Maka tempatku berada itu bersifat kontingen. Eksistensi suatu tempat tergantung dari punya arti atau tidaknya bagi tujuan manusia. Maka akupun masih bebas sepenuhnya seandainya aku meninggalkan pengahayatan terhadap

\footnotetext{
${ }^{18}$ Jean Paul Sartre, (1958), Op.Cit., h. 489.
}

tempat dimana ku berada ini, dalam arti bahwa aku tetap tinggal dalam pengahayatan akan kebebasanku semula. b. My past (masa lampau-ku)

Masa lampau adalah suatu yang mengikat dan mengunci kebebasanku. Masa lampau merupakan sejarah yang tidak mungkin aku lupakan begitu saja, karena masa lampau sewaktu-waktu hadir dalam kekinianku. Konsekuensinya, masa lampau adalah suatu yang dihayati dan mengkristal dalam kekinian, karena masa lampaulah yang membentuk masa sekarang menjadi seperti ini ${ }^{19}$.

Setiap orang pastilah memiliki masa lampau. Maka manusia tidak mungkin akan dapat meniadakan masa lampaunya sendiri, meskipun masa lampau bisa saja dilupakan sebentar, dimanipulasi dan disusun dalam suatu cerita menurut kehendaknya sendiri.

Tetapi Sartre menentang kaum determinis yang mengajarkan bahwa masa lampau menentukan segalanya, sebab masa lampau adalah yang sudah berlalu, sejarah yang telah lewat dan tidak mungkin berulang. Sartre berpandangan bahwa masa depan hanya mendapatkan maknanya justru dalam kebebasanku. Aku tidak daapt berada kecuali dengan meniadakan masa lampauku dan meluncur ke masa depan. Memang manusia tidak dapat merubah masa lampau, seperti pendidikan, orang tua, dan sebagainya. Tetapi aku tetap bebas menuntut masa depanku. Mungkin saja seseorang yang sudah dipersiapkan untuk menjadi dokter tiba-tiba merubah haluannya, meskipun segala pendidikannya diarahkan kesana guna memenuhi cita-citanya dahulu.

Sartre memandang masa lampau sebgai bagian dari sejarah yang tidak

\footnotetext{
${ }^{19}$ Jean Paul Sartre, (1976), Op.Cit., h. 496.
} 
mengurangi kebebasan manusia untuk mengambil keputusan atau memilih alternatif-alternatif yangmenjadi idealnya dan dijatuhkan pada saat sekarang ini. Masa lampau adalah masa lampau dan menoleh kesana jika kita perlu, tetapi harus dibuang dalam arti tidak menjadi dasar atau pengahambat kebebasan hari ini. Oleh karena itu kebebasan tetap menjalankan perannya seperti semula sesuai dengan kehendak. Manusia memberi artri kepada kebebasannya sekaligus menghayatinya sebagai miliknya yang paling berharga.

c. My Environment (lingkungan sekitar$\mathrm{ku})$

Lingkungan sekitar merupakan
kefaktaan dan sekaligus sebagai seperangkat kemungkinanku. Lingkungan sekitar dalam hal ini bukan my place (Sartre, 1976: 504). Lingkungan sekitar yang dimaksudkan adalah mencakup segala sesuatu yang ada di sekitarku dengan segala kegunaan dan ketidak gunaan bagi pemenuhan maksud-maksud manusia. Hal ini meliputi segala sesuatu, baik itu benda, alat yng berada di sekeliling manusia maupun peristiwaperistiwa yang terjadi dengan tiba-tiba dalam perspektif perealisasian kebebasanku, yang pada mulanya mengurangi akan penghayatan atas kebebasanku. Lingkungan sekitar itu lazim disebut dengan unwelt yang adanya tidak dapat dihindari ${ }^{20}$.

Lingkungan sekitar kita hanya mendapat makna dalam konteks cara kita berada yang menjelma dalam keinginankeinginan manusia. Sebagai contoh; hujan hanya merupakan halangan bagiku sejauh keinginanku untuk berangkat kuliah terhambat oleh hujan itu. Tanpa tujuan

\footnotetext{
${ }^{20}$ Fuad Hasan, Op.Cit., h. 147.
}

kuliah, hujan mungkin menjadi rahmat bagiku, karena menyegarkan rumput tamanku. Alhasil, kesemunya itu menunjukkan bahwa bagi Sartre kebebasan masih tetap sebagai kunci, pemberi makna terhadap apa saja yang tampak dalam lingkungan sekitarku. Lingkungan sekitar dapat diabaikan, memakainya, meninggalkannya dalam suatu tindak kebebasan. Kesemuanya tergantung kepada apa yang kita inginkan. d. My Fellowman (adanya sesama manusia)

Adanya sesama manusia merupakan faktisitas yang tidak dapat disangkal. Setiap kehadiran orang lain dengan latar belakang yang khas juga memiliki kebebasan mutlak seperti diriku. Dalam arti tertentu kebebasan orang lain tersebut menjadi batas kebebasanku. Manusia lain masing-masing ingin menyergapku ketika tidak dalam keadaan waspada, ia ingin memperdayai dengan kebebasan yang dimilikinya. Untuk itu tidakj mengherankan jika keberadaan orang lain kemungkinan-kemungkinanku menjadi retak dan sekarang menjadi kemungkinan-kemungkinannya juga. Sebaliknya karena adanya orang lain, aku mendapatkan tempelan ciri-ciri yang asing bagi-ku. Implikasi ini terjadi karena aku tidak bisa menghindar atau mengusirnya, sebab dia memiliki kebebasan yang mutlak seperti kebebasanku. Sebagai contoh, aku disebut pedagang, cantik, jelek, karena kehadiran orang lain. Aku ingin segera memakai kamar kecil untuk membuang hajatku, tetapi pada saat yang sama ada orang lain yang menggunakan. Sebgai akibatnya, kebebasanku untuk memonopoli kamar kecil itu menjadi pecah dengan kehadiran orang lain. 
Akan tetapi kefaktaan manusia tersebut bukanlah mengurangi kebebasannya, karena keadaan yang tampil tersebut bukanlah merupakan pilihannya. Kefaktaan itu justru situasi dimana saya dapat merealisasikan kebebasanku. Saya tetap bebas memilih kemunkinan-kemunkinan. Sebagai contoh, dengan kehitaman kulitkuaku bisa pergi meninggalkan manusia yang berkulit putih. Meskipun demikian bagi Sartre, orang lain adalah maut yang tersembunyi bagi kemungkinan-kemungkinanku. Ia selalu mengintai dan melangkahi kebebasanku dan memasukkan ke dalam kebebasannya tanpa bisa aku hindarkan atau aku halangi, karena dia memiliki kebebasan yang sama sengan diriku ${ }^{21}$.

e. My Death (kematian-ku)

Manusia yang bebas bagaimanapun juga akan menjumpai kematian sebagai daerah batas bagi kebebasannya. Dengan hadirnya kematian, selesailah semua tindakan kebebasan manusai, kematian dirasakan sebagai pengahambat atau halanagan terakhir dari pada kebebasan manusia. Tetapi batas itu di luar eksistensi manusia. Maksudnya, kematian bukanlah suatu yang dapat diartikan menuju kehidupan lain atau memberi arti akhir dari eksistensi manusia.

Bagi Sarte, maut adalah sesuatu yang absurd, sebab maut tidak dapat ditinggalkan, namun hanya diharapkan datangnya. Maut adalah absurd karena datangnya diluar dugaan, tidak dapat dipastikan dan bukan merupakan pilihan manusia sendiri ${ }^{22}$.

Maut tidak memiliki arti apaapabagi eksistensiku, sebab datangnya maut justru akan membekukan

\footnotetext{
${ }^{21}$ Jean Paul Sartre, (1976), Op.Cit., h. 69.

${ }^{22}$ Jean Paul Sartre, (1976), Ibid., h. 533.
}

eksistensiku sehingga menjadi esensi dan tidak berguna lagi selamanya. Implikasinya menjadikan kebebasan yang tidak terbatas itu menjadi porak-poranda, lenyap tanpa bekas bersama maut. Manusia akan kehilangan kebebasan untuk selamanya, kematian mengakhiri kemungkinan-kemungkinan dan hanya akan dapat bermakna bagi orang lain yang masih hidup.

\section{Arah Konsep "Kebebasan" Sartre}

Dari deskripsi konsep kebebasan Sartre di atas, ia memiliki pandangan bahwa manusia dalam perjalanan menuju kesempurnaan eksistensinya dengan dilengkapi bekal untuk sampai ke tujuan tersebut berupa 'kebebasan', eksistensi tanpa kebebasan adalah suatu yang absurd. Namun demikian manusia tidak akan pernah sampai kepada kesempurnaan eksistensi, karena kesempurnaan eksistensi berarti akhir, sesuatu yang tidak dilekati guna, sehingga tugas kemanusiaan adalah mencari titik ideal untuk perkembangan manusia masa depan dengan nilai-nilai kebebasan. Man is freedom, human existence is freedom.

Menurut Sartre, manusia mengalami dilema dalam kehidupannya, ia ingin bebas atau tidak bebas sama sekali. Dan sartre memilih pilihan yang pertama, manusia memiliki kebebasan absolut . Tidak ada batas-batas bagi kebebasan, termasuk faktisitas. Kebebasan tidak dapat di batasi oleh konsepsi yang sudah jadi, hal yang dapat membatasi kebebasan adalah kebebasan itu sendiri.

Ada dua hal yang nampak dalam pemikiran Sartre tentang kebebasan ini, pertama, ia hendak menggusur segala bentuk pemikiran determinis, romantisis dan idealis. Kedua; dia ingin menentang pandangan yang menyatakan bahwa mungkin tanpa disadari manusia telah membangun suatu kondisi tertentu yang 
harus dipertanggungjawabkan. Sartre menolak pandangan yang demikian ini, sebab pada hakikatnya manusia adalah bebas membuat apa saja bagi dirinya sendiri, fakta yang ada dalam dunia sebagai akibat dari aktivitas bebas manusia hanyalah akan memberikan pilihan-pilihan bagi kebebasan manusia dalam membangun eksistensinya.

\section{H. KESIMPULAN}

Bagi banyak orang, kebebasan memiliki dua kutub yang saling melengkapi. Pertama, kebebasan yang menunjuk kepada tidak adanya paksaan dari pihak lain dan biasanya disebut dengan 'kebebasan dari'. Kedua, kebebasan yang mengarah kepada sesuatu, dan sering disebut sebagai 'kebebasan untuk'. Dari uraian konsepsi Sartre tentang kebebasan di atas, maka dapat dilihat bahwa kebebasan dalam konsepsi Sartre adalah 'kebebasan untuk', sehingga selalu membuka jalan bagi setiap kreativitas manusia.

Konsepsi radikal tentang kebebasan yang dirumuskan Sartre menunjukkan penekanan pada kebebasan invidividu secara mutlak tanpa tersekat oleh fakta-fakta yang melingkupinya, walaupun itu fakta kematian sekalipun. Karena setiap faktisitas menurut Sartre akan memberikan pilihan-pilihan bagi individu untuk merealisasikan kebebasannya. My place, my environment, my past, my fellowman dan my death, bukanlah halangan bagi kebebasan.

Kebebasan manusia akan mengantarkannya pada pemenuhan eksistensi kemanusiaannya. Namun manusia tidak akan pernah sampai pada pemenuhan tersebut, karena manusia memiliki akal, nalar yang kreatif yang membuatnya selalu melihat kekurangan dalam eksistensinya. Setiap pemahaman tentang kemanusiaan ataupun ideologi yang telah dirumuskan hanyalah upaya yang sia-sia dan tidak berguna, karena pemahaman manusia tentang eksistensinya serta upaya untuk memenuhi kebutuhan eksistensialnya selalu berkembang, sehingga tidak mungkin dirumuskan dalam bentuk ideologi atau rumusan-rumusan tertentu. Produk pemikiran dan budaya masa lalu hanyalah sekedar pencarian eksistensi manusia pada masa lalu, sesuatu yang telah lewat. Dia tidak membatasi kebebasan dalam perjalanan hidup individu dalam kebebasannya. Man is existence, existence is freedom, man is freedom.

\section{DAFTAR KEPUSTAKAAN}

Anderson, T. C, (1979), The Foundation and Struckture of Sartrean Ethick, The Regents Press, Lawrence.

Bertens, K, (1996), Filsafat Barat Abad XX PRANCIS, Gramedia, Jakarta

Brouwer, M.A.W, (1989), Psikologi Fenomenologis, Gramedia Jakarta

Elmo, Nauman, (1971). The New Dictionary of Existentialism, New York, Philosophical Library.

Hadiwijono, Harun, (1998), Sari Sejarah Filsafat II, Kanisius, Yogyakarta.

Hasan, Fuad, (1989), Berkenalan dengan Eksistensialisme, Pustaka Jaya, Jakarta.

Jones, W.T, (1975), The Twentieth Century to Wittgenstein and Sartre (a History of Western Philosophy), California Institute of Technology, New York.

Nicola, Abbagnano, (1967), 'Humanism' dalam Paul Edward (ed.) Encyclopedia of Philosophy, Vol IV Newyork Mc Millan Publisher. 
Nico, Syukur Dister (1988), Filsafat Kebebasan, Kanisius, Yogyakarta.

Omoregbe, J., (1976), The Positive and Negative Aspect of Jean Paul Satre's Conception of Human Freedom, Oyes Leuven, Roma.

Olafson, F.A, (1976), Jean Paul Sartre dalam Paul Edward, Encyclopedia of Philosophy, Vol VII, Mic Millan, Newyork.

Pudjowijatno, (1990), Pembimbing ke Arah Alam Filsafat, Rineka Cipta, Jakarta.

Raymond, M.M, (1989), Experience of Nothingness ; a form of Humanistic religious Experience, dalam Jurnal of Dharma ed. 173-189

Sanjiwani, Riyanto, (1983), Kebebasan Menurut Sartre, dalam majalah Driyarkara, Tahun XI no 1, oktober, Jakarta.

Sartre, Jean Paul, (1973), NAUSEA (translated by R. Baldick), penguin books, Harmondworth (1960), Existentialism is

Humanism, Trans. Philip mainet, Meutheun co. Itd.. London.

Nothingness $:$ an essay on on
phenomenology ontology, Transl. By H.E. Barnes, Meuthuen, London. (1976) Huis Clos (Pintu

Tertutup), Versi Indonesia oleh Asrul Sani, Pustaka Jaya, Jakarta.

Scruton, Roger, (1986), Sejarah Filsafat Barat Modern (dari Descartes Sampai Wittgenstein) (terj. Zainal Abidin), Pantja Simpati, Jakarta

Suseno, Frans Magnis, (1989), Etika Dasar, masalah-masalah pokok filsafat moral, Kanisius, Yogyakarta.

Wallace, I.M, (1968), A History of Philosophy, Published by Van
Nostrud, Reinhold Company, Newyork. 